\title{
China and the Emerging Global Energy System
}

\author{
C.Vinodan \\ School International Relations and Politics \\ Mahatma Gandhi University \\ India
}

\begin{abstract}
Energy and resource security have become critical issues on the economic and strategic agenda in the Asian region as demand and dependence on imported supplies grow. Energy security cuts across many sectors-economic, environmental and national security. Recent increases in energy prices, climate change and a steady escalation in global energy demand -expected to rise by nearly 60\% over the next 20 years-have led energy policy-makers across the world to engage in a wide ranging debate over how best to address their country's future energy requirements. Regional powers, most notably China, have responded with nationalistic strategies to secure control over energy and commodity supplies. China is trying to shift its role from a passive recipient to an active innovator of international energy rules; from an onlooker to an active participant in international energy affairs; and from a receiver to a contributor of international energy policy. Major Asian powers are now redefining their foreign policy to meet the growing energy needs. This is most evident from the grand strategy adopted by China since 1991. China is destined to become a significant player in key energy- and resource-exporting regions, such as the Middle East, Central Asia, Africa, and Latin America. China's new involvement in these regions could have a powerful impact on the strategic goals of other major power in the world. Asian stability is central to the global prosperity and security; thus, the potential for conflict driven by energy competition and resource insecurity must become a conscious and carefully crafted dimension of energy strategies of all leading players in the region.
\end{abstract}

Keywords: Energy security, geopolitics, sustainability, development, resource governance.

\section{Introduction}

Energy security has emerged as a universal issue in the 21 st century. Energy security cuts across many sectors-economic, environmental and national security. Recent increases in energy prices, climate change and a steady escalation in global energy demand-expected to rise by nearly $60 \%$ over the next 20 years-have led energy policy-makers across the world to engage in a wide ranging debate over how best to address their country's future energy requirements. Similarly, energy security has become a policy priority for most part of the world, especially the rising powers. Availability and access to energy are considered as catalysts for economic growth. Access to energy services is a key component of alleviating poverty and an "indispensable element of sustainable human development," 
in global energy production centres and markets radically altered the international energy order, indicating new challenges to the international system. Contemporary developments in the global energy system and the rise of Asian powers- especially China- marked a turn in international relations and global resource governance. China is trying to shift its role from a passive recipient to an active innovator of international energy rules; from an onlooker to an active participant in international energy affairs; and from a receiver to a contributor of international energy policy. Asian countries are now reshaping the international system. The conditions for international relations are changing to the advantage of large countries with a strong state, and China plays an important role in this process. This paper examines the changing dimensions of global energy order and its implications in international relations. It also looks at the key factors influencing the energy foreign policies of China and its ramifications in the Asian security order. Energy security has been more and more important in Asia as well as in the world today. It is more and more difficult for a single country to make sure its own energy security in the globalized world now. In this backdrop, this paper explored how the quest for energy security has transformed the foreign policies of major powers. The paper argues that energy and resource security have become critical issues on the economic and strategic agenda in Asia as demand and dependence on imported supplies grow. Major Asian powers are now redefining their foreign policy to meet the growing energy needs. This is most evident from the grand strategy adopted by China since 1991 .

\section{Energy Security and Conflict}

Energy security can be defined as a condition in which a nation and all (or most) of its citizens and industries have access to adequate energy resources at reasonable prices for the foreseeable future, free from serious risks of major disruption of service. ${ }^{2}$ Insecurity can arise from various causes, such as geopolitical instability, natural disasters, terrorism, poor regularity designs, or a lack of investments. ${ }^{3}$ The literature on energy security suggests that different countries have developed different strategies for securing their energy supply. ${ }^{4}$ Many aspects of modern life, economies, and the relations between states are shaped by the development of energy resources and technologies. The reliance on energy in every field of life has made energy security tremendously important for states and societies. Especially for modern militaries, securing energy resources has become of utmost importance since the beginning of the twentieth century. Therefore, "second only to national defense," energy security has become a primary concern for the survival and wellbeing of both developed and developing nations. ${ }^{5}$ History proved that First and Second World Wars in the twentieth century were also linked with energy use. Twentieth century history was greatly determined by First Lord of Admiralty Winston Churchill's decision that the British Navy must switch from using coal to petroleum to maintain its hegemony before World War I shaped the course of the war; it also led the Allies to invade the oil-rich territories in the Middle East. Energy resources were even more important in World War II. One of the major reasons that Japan attacked the US was the latter's oil embargo against the former's empire. The Axis powers, lacking substantial energy resources, based their strategies on first gaining access 
to energy-rich areas, such as Romania and the Caspian Sea. The Allies, on the other hand, "floated to victory on a sea of oil" and used nuclear power for the first time to conclude the war. ${ }^{6}$ The modern concern with energy security began with the Arab-Israeli war of 1973-4 and the Organization of Arab Petroleum Exporting Countries (OAPEC) and Organization of Petroleum Exporting Countries (OPEC)'s use of the "oil weapon." OPEC's boycott of major energy-importing countries in Europe and the US has shown how important it is for modern societies to secure their supply of energy; it became clear that an energy crisis can hurt everyone in society, including government, business, and individuals. Consequently, securing energy resources has become a key aspect of foreign policy making of major powers since the 1970s. With the collapse of the Soviet Union in 1991, the concerns for energy security acquired a new dimension: The newly independent energy-rich ex-Soviet republics in the Caspian basin have become a playground for great-power rivalry. The US and EU, both having suffered from dependency on Middle Eastern energy in the 1970s, have begun increasing their political and economic influence on the region to gain access to energy resources. "The New Great Game" was coined as a term to describe the rivalry between the Western powers and a weakened Russia for the control of the Eurasia region and its energy resources. ${ }^{7}$ Since energy-hungry China has begun pursuing aggressive foreign policies to secure the supply of energy to its growing market, this rivalry has taken a "tripolar" shape.

Energy security is a holistic concept which varies from country to country according to need. For the exporting country it implies continuous access of market for the selling of energy sources, whereas, for the importing country, it essentially implies "ensuring uninterrupted supplies of energy to support the economic and commercial activities necessary for the sustained growth of the economy". ${ }^{8}$ The critical relevance of this concept for India and China emanates from a growing imbalance between the demand for energy and its supply from indigenous sources, implying, therefore, growing import dependence for each nation. China's search for energy security has come under close international scrutiny in recent years. This is partly because of the economic impact on other countries - most notably changes in the price and availability of some energy resources. But there are also important political dimensions to these debates. For example, supporters of a liberal global order are concerned that China is undermining attempts to pressure authoritarian states to reform. If such states don't like the conditions that accompany aid and economic relations with the West (or more correctly, some in the West), then -if they have things that the Chinese want they can deal with them instead. They might insist that you don't have political relations with Taiwan, and want guarantees that their investments are safe, but they won't pressure you to liberalise your political or economic systems. And as an added bonus, the repayment terms of Chinese development loans are often cheaper than those offered by places like the World Bank.

\section{New Energy Geopolitics and China's Energy Strategy}

Robust industrial growth and increasing domestic living standards have left China with a nearly insatiable thirst for energy. And oil is playing an integral part in meeting that 
demand. Although coal remains the chief source of energy, oil fuels China's transportation, plays a crucial role in industry, and is a significant input in agriculture. During the height of the Cultural Revolution in 1969, China ranked 25th in world oil demand. Today, China is the world's second-largest consumer of oil and the largest net importer of petroleum and other liquid fuels. China's growing demand for oil comes at a time when the petroleum industry is experiencing perhaps the most significant paradigm shift since the OPEC embargo in 1973. High crude prices combined with technological advances are allowing super majors, petro-states, and independent oil entrepreneurs to unlock a new class of previously unattainable unconventional oils. These oils are globally more abundant and widespread than their conventional predecessors. How China navigates this complex new oil terrain will have far-reaching consequences for domestic affairs, international trade, the environment, and global security. With Beijing's new leadership seeking to ensure that China's economic growth charts a more sustainable path, it is the right time to address the nation's future oil opportunities and challenges.

The rise Asia as a major player in global politics exemplifies the most significant development in the new century. The economies of Asia are growing rapidly. This region has become and continues to be the key driver for the world economy. Along with rapid economic development, energy use has grown fast too and is likely to continue to do so in the future. ${ }^{9}$ However, unlike their developed country counterparts elsewhere who had achieved their industrialization and urbanization without energy security and environmental concerns, the Asian countries, particularly those in East Asia and South Asia, have to face the twin threats of energy security and global climate change in the course of their industrialization and urbanization. ${ }^{10}$ China and India have been hailed as the fastest growing markets in the world. Although the development of these two economies have taken a totally different path altogether, energy security and independence poses a common threat to both these gigantic nations. China followed a socialist economic path in the beginning and later transformed in to market socialism by transforming a largely agrarian economy to a manufacturing based economy which would ultimately lead to a service centric economy. India followed the mixed economy model and later gave thrust to a service centric economy and it is only recently that its manufacturing sector is shaping up to contribute substantially to its economic growth. National and international energy policies of both these countries will decide the future development of these nations. At present, both these economies rely on fossil fuels and coal for most of their energy needs which are growing at a hasty pace. Going forward, both these countries will have to rethink their development agenda in the light of the global warming and the approaching peak oil production. ${ }^{11}$

Energy security, as one of non-traditional security issues, has been more and more important in Asia as well as in the world today. It is more and more difficult for a single country to make sure its own energy security in the globalized world now. In recent years, Asian countries have made some progress in bilateral and multilateral dialogue, cooperation and coordination in energy field. However, they are still far away from a regional architecture of energy security. Over the past decade, Asia has emerged at the center of global energy and 
commodity markets as demand for these commodities has accelerated due to the region's rapid economic growth. This trend is particularly salient in the case of energy. Rapid industrialization, a massive scale of urbanization, rising per capita income, and increased levels of transportation and motorization have all stimulated demand for oil, natural gas, coal, and electricity. Although the boom in energy has been centered in China, regional demand for other raw materials and commodities, including iron ore, copper, aluminum, and rare earth minerals essential for a range of high-tech products and defense applications, has also skyrocketed. Owing to Asia's relatively limited resource base in many of these raw materials, the region's import dependence for critical energy and industrial inputs is rising dramatically. Moreover, the geographic distribution of resources Asia needs to fuel economic growth is highly uneven, particularly in the case of energy. A rapidly rising share of Asia's petroleum will need to be imported long distances from the Persian Gulf and Africa, historically unstable regions of the world. Consequently, there is a profound and growing sense of insecurity across the region over the reliability of future energy supplies and fears that shortages or disruptions could become severe bottlenecks to continued economic growth and political stability. ${ }^{12}$ For most Asian governments, particularly in China, economic performance and job creation are seen as ensuring the bedrock for political legitimacy and stability. Similar anxieties are beginning to affect markets for and investments in other key raw materials. For example, concerns over supplies of rare earth minerals have begun to intensify competition to lead the way in high-tech clean energy products while heightening the potential national security consequences of shortages of materials necessary for critical military applications. Consequently, energy security and security of supplies of other key raw materials have increasingly become a matter of the "high politics" of national security rather than just the "low politics" of domestic energy and economic policy. ${ }^{13}$

China has enjoyed rapid economic growth ever since it embarked on reform and opening up to the world in 1979, although the speed has varied from time to time. The surge forward was particularly impressive from the start of twenty-first century until the financial crisis, with the economy zipping along at a double-digit growth rate. In recent years, its economy has turned into a driving locomotive for the entire Asian continent. Undoubtedly, the country has become an important factor in global politics and economics with a tremendous impact on the political, social and economic development of all other states on our planet. Today's emerging new world order is unimaginable without China playing a crucial role in it. ${ }^{14}$ China has achieved remarkable economic growth during the past three decades, with Real Gross Domestic Product increasing at an average annual rate of over 10\% between 1978 and 2008 (World Bank, 2009). China's rapid growth since 1978 has been highly dependent on energy. As its economy has expanded, energy use has increased by over $200 \%$ and by nearly $150 \%$ per capita, with over half of this growth occurring in the years since 2001 . This tight connection between growing energy use and economic development means that energy policy is a central concern of the government. Following its economic development, China's demand for energy, particularly oil, has skyrocketed. According to IEA research, almost half of global oil demand growth in the next five years will come from China (See figure 1). Looking farther ahead, the scenarios in the IEA's World Energy Outlook $2010^{15}$ 


\section{C.Vinodan}

shows China importing $79 \%$ of the oil it consumes by 2030, and accounting for a larger increment in oil demand than any other country.

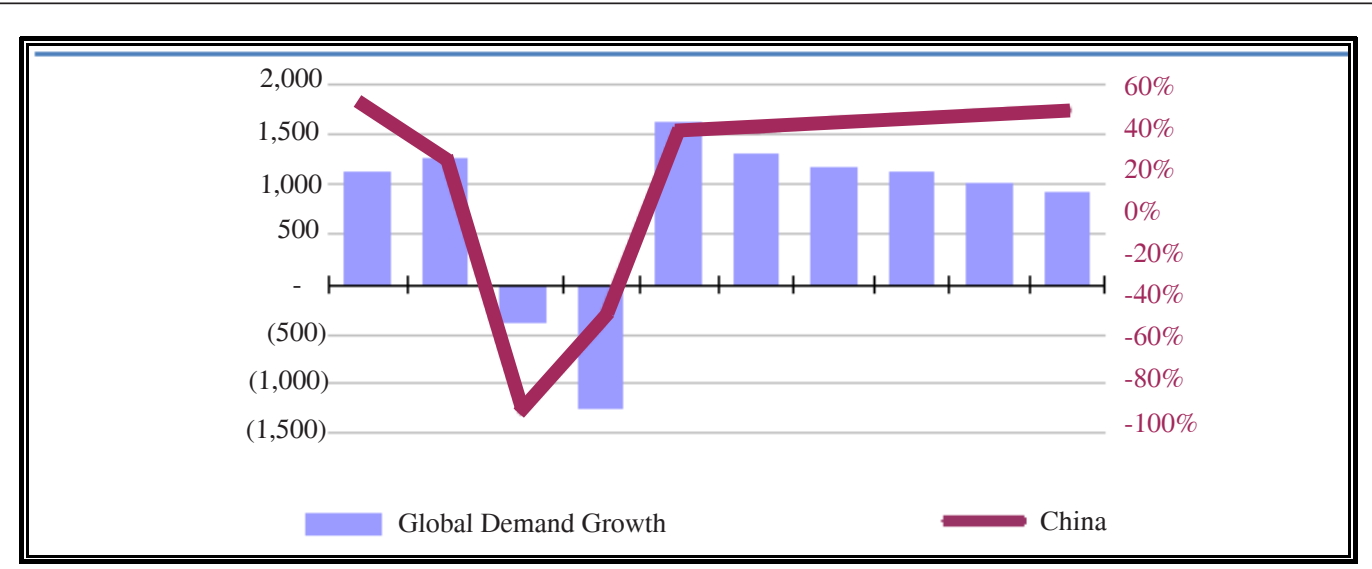

Figure 1. China's contribution to oil demand growth, 2010-15, kb/d

Source. IEA, 2010

In terms of total energy consumption, oil accounted for $16.6 \%$ in 1990 , peaked at $22.3 \%$ in 2002, and has gradually declined thereafter to 16.5 in 2010( See Table 1). Coal has always been the main form of energy in China, largely due to its vast reserves (third largest in the world) that are available in varying quality all over the country. Until the 1980s, coal was used in power generation, industry, and transport, but today it is almost exclusively used for power generation (accounting for $76.8 \%$ of total electricity generated in 2010) and in some heavy industries ${ }^{16}$. The country also has extensive hydropower resources, accounting for $16.3 \%$ of electricity generation in 2010; in the same year natural gas accounted for 1.7 , nuclear power for 1.8, and wind and other renewable sources for 1.2\%. Oil accounted for only $2.2 \%$ of electricity generation, much less than it did in earlier years (China Electricity Council, 2011).

Industrialization and improvement in living standards have entailed a surge in energy consumption. China has passed the U.S. to become the world's biggest energy consumer, according to new data from the International Energy Agency, a milestone that reflects both China's decades-long burst of economic growth and its rapidly expanding clout as an industrial giant. ${ }^{17}$ China's ascent marks "a new age in the history of energy," IEA chief economist Fatih Birol said in an interview. The country's surging appetite has transformed global energy markets and propped up prices of oil and coal in recent years, and its continued growth stands to have long term implications for global energy security. From 1990 to 2010, oil production rose from $138.3 \mathrm{mt}$ to $204.7 \mathrm{mt}$ but Chinese oil consumption soared from $114.4 \mathrm{mt}$ to $458.1 \mathrm{Mt}$. While the growth rate of domestic production of crude oil dipped 
Table 1

The Role of Oil in China's Total Energy Consumption, 1990-2010 (\%)

\begin{tabular}{ccccc}
\hline Year & Coal & Crude oil & Natural gas & $\begin{array}{c}\text { Hydropower } \\
\text { nuclear power } \\
\text { wind power }\end{array}$ \\
\hline 1990 & 76.2 & 16.6 & 2.1 & 5.1 \\
1991 & 76.1 & 17.1 & 2.0 & 4.8 \\
1992 & 75.7 & 17.5 & 1.9 & 4.9 \\
1993 & 74.7 & 18.2 & 1.9 & 5.2 \\
1994 & 75.0 & 17.4 & 1.9 & 5.7 \\
1995 & 74.6 & 17.5 & 1.8 & 6.1 \\
1996 & 73.5 & 18.7 & 1.8 & 6.0 \\
1997 & 71.4 & 20.4 & 1.8 & 6.4 \\
1998 & 70.9 & 20.8 & 1.8 & 6.5 \\
1999 & 70.6 & 21.5 & 2.0 & 5.9 \\
2000 & 69.2 & 22.2 & 2.2 & 6.4 \\
2001 & 68.3 & 21.8 & 2.4 & 7.5 \\
2002 & 68.0 & 22.3 & 2.4 & 6.3 \\
2003 & 69.8 & 21.2 & 2.5 & 6.5 \\
2004 & 69.5 & 21.3 & 2.5 & 6.7 \\
2005 & 70.8 & 19.8 & 2.6 & 6.8 \\
2006 & 71.1 & 19.3 & 2.9 & 6.7 \\
2007 & 71.1 & 18.8 & 3.3 & 6.8 \\
2008 & 70.3 & 18.3 & 3.7 & 7.7 \\
2009 & 70.4 & 17.9 & 3.0 & \\
2010 & 70.9 & 16.5 & 4.3 & \\
\hline
\end{tabular}

Source. National Bureau of Statistics, 2011

from 1996 to 2000, consumption grew at 8.15\%, peaking in the 2001-2005 period. As it became more dependent on imported oil, China came under increasing pressure to secure reliable supplies. In 2001, the country devised the zou chuqu (go out, go global) policy, instructing and motivating state-owned and private Chinese enterprises and banks to become closely involved in natural resource procurement and infrastructure development abroad to secure resources that China could not supply itself. In short, the Chinese government no longer abhors the idea of importing oil, as it can use its enormous foreign exchange reserves (steadily amassed since the 1980's) to help leverage loans for oil deals, such as those negotiated in recent years with Russia, Brazil, Venezuela, Kazakhstan, Ecuador, and Turkmenistan. 
Between 1993 and 2006, China's oil consumption nearly doubled from 2.9 million barrels per day (b/d) to 7 million, representing an annualized growth rate of $7 \% .{ }^{18}$ China's coal consumption in 1980 was about 603 million standard coal equivalent (SCE) tons but by 2007 it had grown to 2.655 billion SCE (Bo 2010). China's domestic energy supply has not expanded to keep up with such enormous growth in demand, and by 2009, the PRC was one of the largest net energy importers in the world. Reliance on oil imports has become particularly acute. China became a net oil importer in 1991, and by 2008, it imported about 3.6 million barrels of oil per day. ${ }^{19}$ By 2020 , China is projected to import somewhere between 60 and $80 \%$ of the oil it will consume. ${ }^{20}$ Chinese demand for imported oil accounted for $4.5 \%$ of the global total in 1993 , and by 2006 , it was the world's second largest consumer, accounting for $8.6 \%$ of total demand. Over a third of total global demand growth during the past five years has come from the PRC. By 2030, China is expected to be the world's largest consumer of oil, with demand outpacing that of the Japan and Europe combined. ${ }^{21}$ Domestic supplies of natural gas and coal are more abundant for the PRC. Still, it appears as though China's ability to meet domestic demand for energy will depend on its success in expanding imports for the foreseeable future..$^{22}$ This means that China's energy security strategy plays an incredibly important role in its overall foreign policy approach. ${ }^{23}$ Internationally, China's energy security strategy is based on the importance of expanding supply access and stability. This leads to four specific objectives: Increasing and diversifying overseas investments, building additional import avenues such as transnational pipelines, establishing a strategic petroleum reserve, and engaging in so-called oil diplomacy with important supplier states.

\section{China's New Global Energy Diplomacy}

China's rapid development has drawn worldwide attention and has been referred to as a "peaceful rise" in recent years. The country's booming economy feeds Beijing's insatiable thirst for sufficient, stable, and secure energy sources. ${ }^{24}$ China's integration into the global economy has led to a transformation of its foreign policy. ${ }^{25}$ Traditionally China has tried to remain self sufficient and mainly relied on domestic energy resources to drive its centrally planned economy. Since the economic liberalisation of the Eighties, energy consumption has dramatically increased and domestic supply cannot cover domestic demand anymore. China's economic as well as political rise is leading to tensions with its neighbours in the region as well as with other actors on the global political stage. The buildup of China's army coincides with the re-orientation of China's foreign policy towards securing access to energy and mineral resources ${ }^{26}$. The most significant aspect of China's new energy diplomacy is to expand and diversify energy sources to meet the growing gap between domestic supply and demand. In this context the PRC has placed on emphasis on expanding the number and diversity of overseas sources of oil imports. This strategy not only increases the overall supply of energy available to the Chinese economy, it mitigates the effect of country-specific supply disruptions and decreases the political leverage that any single supplier state enjoys vis-a -vis the $\mathrm{PRC}^{27}$. China's National Oil Companies are among the world's largest companies. In 2009, at a time when most international oil companies cut 
back on their investment spending, Chinese NOCs, along with other Chinese companies, invested in 10 overseas acquisitions for a total of USD 18.2 billion. In the same year, China imported just under four million barrels per day (mb/d) of crude oil, up 14\% from 2008, and the first year that China imported more than half $(51.3 \%$ according to IEA data) of its crude oil consumption. China started to import LNG only in 2006, and began importing pipeline gas in early 2010. To many Chinese policy makers and scholars, this dependence on imported energy is a harsh reality they must face, and a spur to action.

The PRC became a net oil importer in 1991 and the China National Petroleum Corporation (CNPC) became the first Chinese National Oil Corporation to enter into the international market when it purchased an oilfield in Peru. Since then, CNPC, Sinopec, and the China National Offshore Oil Corporation (CNOOC) have made significant equity investments in at least 30 countries in the Middle East, Central Asia, Latin America, North America, Russia, and $\mathrm{Asia}^{28}$. These equity investments guarantee China's rights to specific exploration, production, and import rights within the host country. By 2005, the value of overseas investments was approximately $\$ 10$ billion. Between 2005 and 2009, investments expanded rapidly, first as a result of increasing crude prices and then later because of merger and acquisition (M\&A) activities and so-called loans-for-oil opportunities that resulted from the worldwide economic slowdown ${ }^{29}$. Despite China's efforts to diversify its sources of energy supply, most of China's projected oil imports will continue to come from a small number of countries. In 2009, the top ten crude oil suppliers to China (in order of import volumes) were Saudi Arabia, Angola, Iran, Russia, Sudan, Oman, Iraq, Kuwait, Libya and Kazakhstan. As many other net oil importers, especially in Asia, China relies heavily on suppliers in the Middle East with $47 \%$ of its total imports in 2009 originating from there. That high degree of reliance is unlikely to change, even though China has been diversifying supply to Africa, Central Asia, Latin America and Russia, where NOCs are seeking to expand their upstream activities.

The NOCs most frequently cited objectives for investing internationally are to increase their oil and gas reserves, to expand production and to diversify their sources of supply. ${ }^{30}$ These goals are now supported at the highest levels of government; when the State Council level National Energy Commission (NEC; authorised in 2008 and formed in January 2010) met for the first time in April 2010, "securing energy supply through international cooperation" was declared to be one of its six major areas of focus. This is the latest expression of the "Going Abroad" policy. This concept dominates the narrative concerning the actions of the Chinese companies, which are seen by many as responding to a political concern with energy security, despite the reforms that have made the NOCs independent entities. By the spring of 2010, Chinese NOCs had made almost 300 overseas equity investments, valued at over $\$ 200$ billion (Sainsbury, 2010). In a single tour of Latin America in 2009, Vice President Xi Jinping signed a deal with Petrobras in Brazil valued at approximately $\$ 11$ billion and agreed to triple Chinese rights to Venezuelan oil in an agreement with Venezuelan leader Hugo Chavez valued at approximately $\$ 8$ billion. ${ }^{31}$ Prospects for cooperation between the PRC and Venezuela seem favorable down the road, as Chavez declared that, "all the oil 


\section{C.Vinodan}

China needs for the next 200 years-it's here. It's in Venezuela',32. Outright acquisition of foreign oil companies has been a trickier process for China's NOCs. After CNOOC's very public failure to acquire Unocal in 2005, Chinese leaders were sensitized to the political baggage that came along with the expanding global activities of the NOCs. But the 20082009 economic recessions depressed the market value of many firms and, looking for a way to invest over $\$ 2$ trillion in foreign exchange holdings, the PRC decided to redouble its M\&A efforts. Between June 2009 and June 2010, Chinese NOCs spent approximately \$25 billion on M\&A, accounting for over one-fifth of the global total during that period. The PRC plans to spend at least $\$ 60$ billion more on energy-related mergers and acquisitions in the next 10 years. ${ }^{33}$

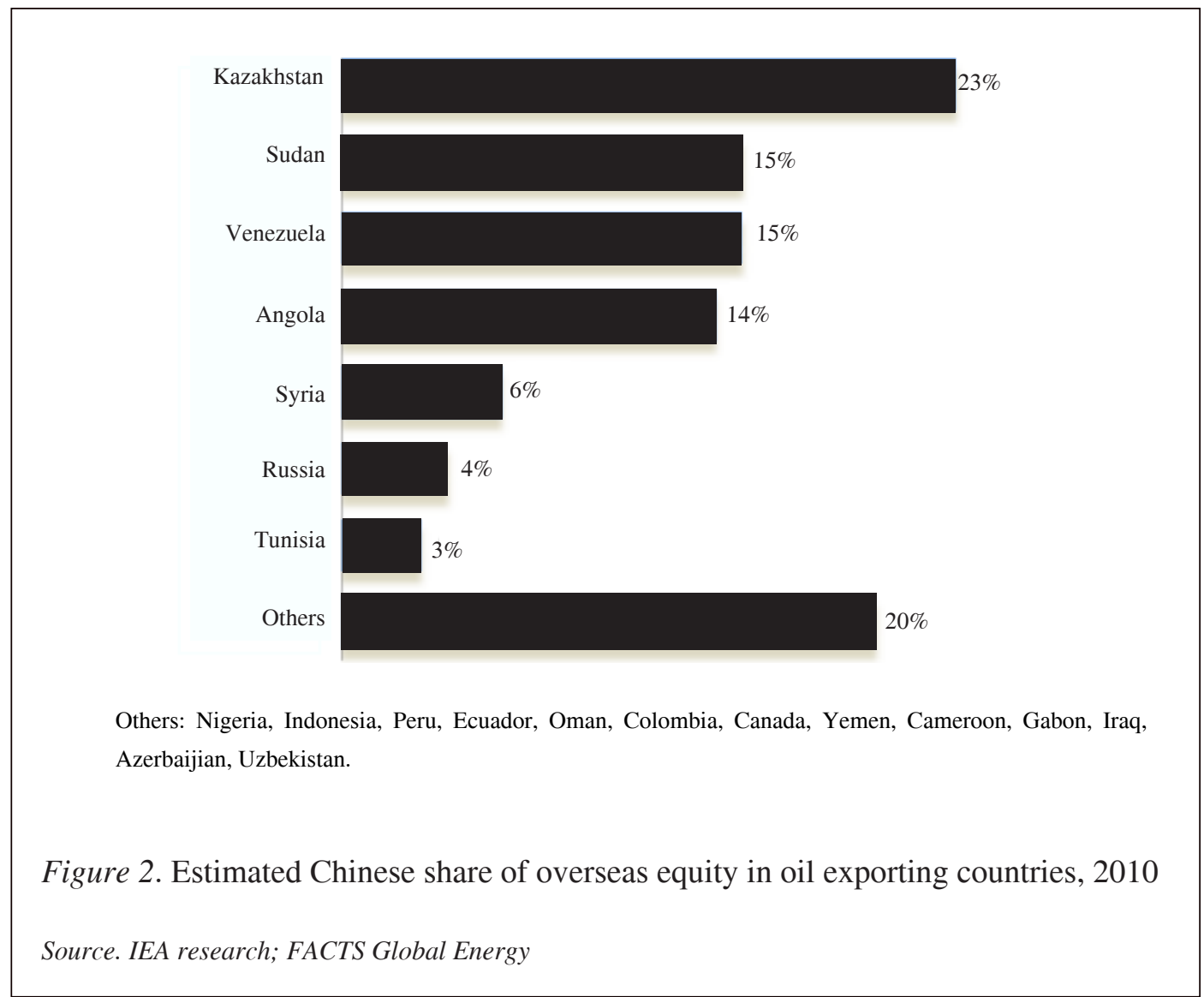

The economic downturn during 2008 and 2009 also led to a large number of "loans for oil' deals between Chinese NOCs and resource-rich, capital-poor countries. These deals comprised about $70 \%$ of the overall investments made by the NOCs in 2008 and 2009 (US Energy Information Administration 2009). Loans were part of the larger deals with Brazil and Venezuela described above, but the PRC also made agreements with Russia (\$25 
billion), Kazakhstan ( $\$ 5$ billion), Turkmenistan (\$3 billion), and Ecuador ${ }^{34}$. Altogether, these agreements have given China the rights to import nearly 75 million tons of crude oil every year ${ }^{35}$. China's overseas investments are designed to give the PRC access to greater amounts of oil and also to diversify the sources from which it imports. CNPC (and its publicly traded subsidiary PetroChina) is most active in terms of overseas investments with about $80 \%$ of total Chinese foreign equity production. According to IEA data, successful acquisitions allowed China's NOCs to expand their overseas equity shares from $1.1 \mathrm{mb} / \mathrm{d}$ in 2009 to $1.36 \mathrm{mb} / \mathrm{d}$ in the first quarter of 2010. Chinese oil companies are now operating in 31 countries and have equity production in 20, though their equity shares are mostly located in four countries: Kazakhstan, Sudan, Venezuela and Angola ( See Figure 2). The increased equity oil level is due to the new acquisitions and higher levels of production in Kazakhstan in early 2010.

\section{Towards Central Asia and Africa}

China's quest for imported oil has changed with corresponding global and regional geopolitical and economic developments over time in response to geopolitical and transportation risks. Though West Asian countries continue to be the most important suppliers of almost half of China's imported oil, China has attempted to decrease its dependence on imports from the volatile West Asia through investments in African countries such as Angola, Sudan, Libya, and the Congo; and Russia and Central Asian countries such as Kazakhstan. Chinese energy strategists believed that investments in the Central Asian countries can also significantly decrease sea-lane transportation risks. In this context, China turned towards the Shanghai Cooperation Organisation (SCO), for its new energy diplomacy in Central Asia. The government in Beijing encourages its state energy companies to invest in new cross-border energy projects and a trans-Asian energy infrastructure. Because many recent oil and gas investments have been in Central Asia and Russia and because it is looking for additional ways to physically transport energy from overseas back to China, the PRC has been expanding both its domestic and international pipeline operations. China has an extensive domestic pipeline network that is growing by about 6\% per year (US Energy Information Administration 2009). Although most pipelines are still concentrated in the industrialized Eastern region, the Urumqi-Lanzhou pipeline opened in 2007 and allowed oil to be shipped from Western China and beyond to the Eastern markets by both pipeline and rail. However, China's energy rich neighbour, Russia, is also perceived as an unreliable supplier. Many of Russia's energy supply promises have gone unfulfilled with the price of Russian oil imports quadrupling in 2005 from the previous year while the actual delivery fell short by 8 million tons from the promised delivery of 15 million tons. China is also wary of Russia's aggressive and unpredictable oil diplomacy that often caters to the Kremlin's political and economic aspirations. Given China's uncomfortable dependence on the US and Russia, and lack of opportunity in the traditional oil fields in the Middle East, the government has intensified efforts to diversify imports. As a latecomer in the world energy market, China's unpopular energy investments in some of the oil-rich "rogue" states such as Iran, Sudan, Burma and 
Venezuela ${ }^{36}$, have spurred international criticism. However, China's subprime investments that exacerbate its relations with the Western countries and undermine UN sanctions are largely inevitable. "In most parts of the world where the biggest [energy] opportunities are, the Western majors are already there," says Philip Andrews- Speed, a China energy expert at Scotland's University of Dundee in Edinburgh. In addition to the premium that Chinese companies often pay for energy asset acquisitions, China's scramble for energy investment opportunities could undermine the vision for becoming a responsible global power. ${ }^{37}$

Central Asia has increasingly become a corner stone of China's energy security policy. On the diplomatic side, China has emphasized regional cooperation that encompasses Russia and Central Asia on important energy issues. Out in the oil fields, Chinese national oil companies continue to compete fiercely for multi-billion dollar deals to acquire and develop oil reserves. The proximity of the oil fields and relatively weak US presence in the region make Central Asia an attractive energy supplier whose energy interests have not already been dominated by major western oil companies. Compared to China's regional competitor Russia or the politically unstable West Asia, Central Asia could effectively diversify its energy sources and better absorb supply shocks that could threaten China's economic development. For energy rich Central Asian countries such as Kazakhstan, Uzbekistan, and Turkmenistan, Chinese investment has been viewed as a potential leverage against Russian control over their access to international energy market. As the Chinese national oil companies construct gas pipelines from the landlocked Central Asia, the region's reliance on Russian pipelines is likely to diminish, thereby undermining Russia's control over the region's energy resources and economic development. As such, China's aggressive energy policy may jeopardize China's relations with Russia, who is reclaiming its international influence in times of high oil prices. To make the emerging situation in its favour China is giving greater significance to regional cooperation arrangements. One example of such increased regional cooperation is the SCO. ${ }^{38}$ Inside the SCO, China and Russia are the two dominating players. The relationship between both countries can be described as an uneasy mix of cooperation and competition for regional influence. For China, however, oil and hopes for turning the old Silk Road across Central Asia into an "energy road" has increasingly become a priority. ${ }^{39}$ Some experts, including Lieutenant General William Odom, senior fellow at the Hudson Institute, say that SCO serves as a vehicle for Russia and China to assert their influence in Central Asia and curb US access to region's vast energy supplies. ${ }^{40}$ But the competition between China, Russia, and other regional powers as India and Iran, for dominance inside of the organization might however hamper its future development into a strong and effective alliance.

China's first important transnational pipeline opened in 2006 and connected Xinjiang province to imports coming from Kazakhstan. The project was completed by CNPC and a Kazakh firm called KazMunaiGaz. ${ }^{41}$ The pipeline has a current capacity of approximately 200,000 barrels per day, but is being expanded and will be able to transport twice that amount by the end of 2011. This pipeline also connects the PRC to a line coming from Western Siberia. In the Russian Far East, the Eastern Siberia-Pacific Ocean (ESPO) pipeline 
is being completed in two stages and will include a spur line that will link northeast China to about 300,000 barrels per day from Eastern Siberia and offshore fields in the Pacific. Chinese NOCs have also upgraded their refining capabilities in order to widen the range of imported crude that they are able to process. Historically, Chinese refineries have been designed to accommodate light and sweet crude. This prevented the PRC from relying too heavily on Middle Eastern imports, which tend to be heavy and sour. In recent years, however, refining capacity has rapidly grown to accommodate Middle Eastern imports, and also the high-acid and high-sulfur varieties that come from African exporters like Sudan. A third additional import avenue will be available once construction is completed on a $\$ 3$ billion oil and gas pipeline that will run from the port of Kyaukryu in Myanmar to the Chinese city of Ruili in Yunnan province. The 1,500-mile pipeline will eventually end in Kunming, allowing about 150,000 barrels of oil per day and natural gas imports from Central Asia and the Middle East to enter China without passing through either the Malacca or Lombok Straits. Further down the road, there has been talk of developing a pipeline through Pakistan to the port of Gwadar on the Arabian Sea. The port, which was financed with over $\$ 1.2$ billion by CNPC, is currently linked to China via the Karakorum highway, which is notoriously narrow and subject to closures due to cracking or obstruction from landslides. The PRC has invested over $\$ 300$ million to upgrade the highway, increase rail capacity running to Gwadar, and there is even talk of launching a spur line to Gwadar off of a hypothetical Trans-Afghanistan Pipeline. ${ }^{42}$

\section{New Oil Diplomacy and Africa policy}

Geographical diversity has been an important objective of China's new energy diplomacy. While half of PRC's oil imports come from the Middle East, a full $30 \%$ comes from Africa, while only three \% comes from the Asia-Pacific region (US Energy Information Administration 2009). China's heavy involvement with oil-rich countries around the world has led to closer ties with some of its most important energy suppliers. Between 2003 and 2007, estimates of China's foreign assistance grew from $\$ 1.3$ billion to approximately $\$ 25$ billion. Over half the assistance took the form of government investment, about $40 \%$ concessional loans, and about $5 \%$ was comprised of grants or debt cancellation. ${ }^{43}$ Geographical distribution of the assistance was notable, with 44\% going to Africa, 36\% to Latin America, and $22 \%$ to Southeast Asia. China's new Africa policy has been widely discussed in the Western press and development politics. China has been blamed to subordinate democracy and human rights to its economic interests and to back up unsavoury regimes like Sudan with foreign investments as well as by selling weapons and providing diplomatic support. On the other hand, China has become Africa's biggest donor of development aid. African countries like Angola have replaced loans from international donors, e. g. the International Monetary Fund (IMF), that come with a whole range of governance conditions, with grants from China, that come with no strings attached. Most Chinese development aid goes to countries where Chinese companies invest in resource extraction or other economic interests. Chinese development cooperation and diplomacy has transformed the playing field on the 
African continent and has pushed other international donors to the side. Recipients of PRC assistance tend to be the same countries that are increasingly important energy providers to China. Approximately $45 \%$ of assistance was directed to the natural resource sector and approximately $43 \%$ was dedicated to infrastructure projects. In addition, nearly $70 \%$ of China's investments in infrastructure projects are in Angola, Nigeria, Ethiopia, and Sudan, three of which are major oil exporters to the PRC. ${ }^{44}$ These figures all lend credence to the argument that China's energy objectives are guiding its emphasis on developing soft power influence in certain countries. ${ }^{45}$ The Chinese may also be using arms sales as a way to facilitate energy deals with host states. According to the SIPRI Arms Transfer Database, Pakistan, Iran, Egypt, Myanmar, Sudan, and Venezuela were six of the nine largest recipients of Chinese arms between 2000 and $2009 .{ }^{46}$ Sudan, for example, has purchased Chinese tanks and aircraft and has relied on Chinese assistance to construct small-arms factories (Eurasia Group 2007. China is seen to be the primary military benefactor of other controversial regimes like Myanmar, through which the PRC is currently constructing a massive oil and gas pipeline.$^{47}$ It is important to note that many Chinese arms transfer agreements were in place before the PRC began importing oil from the countries in question. Countries like Iran and Angola received large shipments of Chinese weapons well before the 1990s, and for reasons that had more to do with their ongoing conflicts than China's energy needs.

The motivation for Chinas decision to provide defense capabilities to oil exporting countries for at least two reasons related to its search for energy security. First, arms transfers can generate leverage for the PRC if the recipient state becomes reliant on Chinese weapons and / or technology. Second, Chinese weapons may increase the ability of the recipient government to maintain stability within its country, thus protecting existing equity investments made by Chinese NOCs. China's alleged "oil diplomacy" is also defined by Beijing's behavior in key international organizations and by high level visits between Chinese officials and various leaders of energy-rich states. Organizationally, Beijing has used its veto-wielding seat on the United Nations Security Council (UNSC) as a way to delay, and or water-down sanctions against both Sudan and Iran. While finally agreeing to a peacekeeping force in Sudan in 2007 and more stringent sanctions against Iran in 2010, the Chinese have used their institutional influence in the UNSC in order to prevent any drastic and potentially destabilizing action against two of their largest sources of imported oil. The PRC has also chosen to use international organizations like the Shanghai Cooperation Organization (SCO) to engage members like Russia and Kazakhstan on energy issues.

\section{Conclusion}

Energy and resource security have become critical issues on the economic and strategic agenda in the Asian region as demand and dependence on imported supplies grow. Regional powers, most notably China, have responded with nationalistic strategies to secure control over energy and commodity supplies. China, India, and other countries in the region are also becoming major energy investors in Iran, Sudan, Myanmar, and other pariah states. The 
global energy and raw materials sector was gripped by what many called a "super-cycle" of long-term commodity price increases. While major regional powers seek to ensure access to key commodity supplies, energy and resource nationalism and a "zero-sum" atmosphere over controlling future oil, energy, and commodity supplies have become a source of regional rivalry, tensions, and potential conflict. Competition and national suspicion over control of energy and other resources is spilling over and affecting the tenor of the region's most important strategic rivalries-most importantly, the rivalry between the United States and China. Driven by needs for energy and raw materials, China is destined to become a significant player in key energy- and resource-exporting regions, such as the Middle East, Central Asia, Africa, and Latin America. China's new involvement in these regions could have a powerful impact on the strategic goals of other major power in the world. Moreover, given that Asia lacks a regional architecture and the institutions to manage conflict, such competition has the potential to destabilize the region. Asian stability is central to the global prosperity and security; thus, the potential for conflict driven by energy competition and resource insecurity must become a conscious and carefully crafted dimension of energy strategies of all leading players in the region.

\section{End Notes}

1 IEA: International Energy Agency. (2011). Retrieved from http://www.iea.org

2 Hancher, L., \& Janssen, S. (2004). Shared competences and multi-faceted concepts - European legal framework for security of supply. In B. Barton, C. Redgwell, A. Ronne, \& D. N. Zillman (Eds.). Energy security: Managing risk in a dynamic legal and regulatory environment (pp. 85 - 119). Oxford: Oxford University Press.

3 Redgwell, C. (2004). International energy security. In B. Barton, C. Redgwell, A. Ronne, \& D. N. Zillman (Eds.). Energy security: Managing risk in a dynamic legal and regulatory environment (pp. 17 - 46). Oxford: Oxford University Press.

4 The UN-mandated and US-led coalition's campaign to secure Kuwaiti sovereignty in 1990 and 1991 can be understood within this context. The US and others prevented Iraq from becoming the second-largest oil producer in the world, controlling the Persian Gulf transit and threatening Saudi Arabia, the largest oil producer, militarily. It is also argued that the US and UK's military intervention in Iraq in 2003 can be evaluated in this context. As the argument goes, especially after the 9/11 attacks, the nature of US-Saudi relations has become ambiguous in ways that might have led the US and UK to unlock the Iraqi oil potential for world markets by removing the Baath regime.

5 Hamilton, L. H. (2005). Foreword. In J. H. Kalicki, \& D. L. Goldwyn (Eds.). Energy and security: Toward a new foreign policy strategy (p. xxi). Washington: Woodrow Wilson Center Press.

6 Barton, B., Redgwell, C., Ronne, A., \& Zillman, D. N. (Eds.) (2004). Energy security: Managing risk in a dynamic legal and regulatory environment. Oxford: Oxford University Press. 


\section{C.Vinodan}

7 Kleveman, L. (2003). The new great game: Blood and oil in central Asia. New York: Grove Press.

8 Willrich, M. (1975). Energy and world politics.New York: Free Press. p. 67.

9 Yunchang Jeffrey Bor, \& ZhongXiang Zhang. (2010). Asian energy in the context of growing security and environmental concerns. Energy Economics, 32(1),1-2.

${ }^{10}$ Yunchang Jeffrey Bor, \& ZhongXiang Zhang. (2010). Asian energy in the context of growing security and environmental concerns. Energy Economics, 32(1),1-2.

${ }^{11}$ All of the historical energy data in this section is drawn from "BP Statistical Review of World Energy 2009," BP plc, June 2009. There are other good sources of energy data and forecasts, including the annual World Energy Outlook by the International Energy Agency (IEA), the U.S. Department of Energy's annual International Energy Outlook (IEO), and an annual forecast from ExxonMobil. These, however, are primarily forecasts with limited historical and country-by-country data. BP's annual publication is the only consistent and detailed annual country-by-country, fuel-by-fuel source of historical data, and it is also the most widely available.

12 Aaron L. Friedbe. (2010). The geopolitics of strategic Asia 2000-2020. The National Bureau of Asian Research, Washington D.C.; Lord, Malloch-Brown. (2010). Is Asia's rise inevitable? Asian Affairs, XLI(III), November.

${ }^{13}$ For an earlier look at the geopolitics of energy security in Asia, see, see Mikkal E. Herberg, "Asia's Energy Insecurity: Cooperation or Conflict?" in Strategic Asia 2004-05: Confronting Terrorism in the Pursuit of Power, ed. Ashley J. Tellis and Michael Wills (Seattle: The National Bureau of Asian Research, 2004), 349-78.

${ }^{14}$ Hauser, Gunther / Kernic, Franz (Eds.) (2009). China: The Rising Power Frankfurt am Main, Berlin, Bern, Bruxelles, New York, Oxford, Wien (pp. 215-16).

15 World Energy Outlook. (2010). Retrieved from www.worldenergyoutlook.org/media/weo2010. pdf.

${ }^{16}$ Dennis Best, \& Ellina, Levina. (2011). Facing China's coal future : Prospects and challenges for CCS. International Energy Agency. Retrieved from www.iea.org/publications/insights/chinas_coal_ future.pdf.

17 Spencer, Swartz, \& Shai, Oster. (2010, July 18.). China tops U. S. in energy use. The Wall Street Journal.

${ }^{18}$ EIA (Energy Information Agency). (2005, August). Country analysis briefs China, 2005. Retrieved from http://www.eia.gov/emeu/cabs/china.html

${ }^{19}$ International Energy Agency. (2009). Key world energy statistics. Paris: IEA.

${ }^{20}$ Downs, E. S. (2004). The Chinese Energy Security Debate. The China Quarterly, 177, 21-41. 
${ }^{21}$ Rosen, D., \&Trevor Houser. (2007 May). China energy: A guide for the perplexed. Peterson Institute for International Economics. Retrieved from http://www.petersoninstitute.org/publications/ papers/rosen0507.pdf.

${ }^{22}$ Downs, E. S. (2004). The Chinese Energy Security Debate. The China Quarterly, 177, 21-41.

${ }^{23}$ Zweig, David, \& Jianhai, Bi. (2005) China's Global Hunt for Energy. Foreign Affairs, 84(5), 2538.

${ }^{24}$ Wen-Sheng Chen. (2010). China's oil strategy: "Going Out" to Iran. Asian Politics \& Policy, 2 (January/March), 39-54,

${ }^{25}$ Wacker, G. (Ed.) (2006). Chinas Aufstieg: Rückkehr der Geopolitik? Berlin: Stiftung Wissenschaft und Politik (SWP-Studie 2006/S 03), Publications of the German Development Institute Nomos Verlagsgesellschaft; Scholvin, S. (2007). Die Energiepolitik neuer regionaler Führungsmächte, Hamburg: German Institute of Global and Area Studies / Leibniz-Institut für Globale und Regionale Studien (GIGA Focus 5).

${ }^{26}$ Economist. (2007, August 4). Briefing: China's military might - The long march to be a superpower.

${ }^{27}$ Stratford. (2010, February 11). China: The dragon of inflation. Stratford Analysis.

${ }^{28}$ Houser, T. (2008). The roots of Chinese oil investment abroad. Asia Policy 5 (January), pp.141166.

${ }^{29}$ Cheng, Joseph Y. S. (2008). A Chinese View of China's Energy Security. Journal of Contemporary China, 17(55), 297-317.

${ }^{30}$ Between 2000 and 2010, Chinese NOCs signed billion-dollar investment deals involving equity ownership of oil resources in countries like Iran, Venezuela, Nigeria, and Kazakhstan (US Energy Information Administration 2009). In other countries like Angola, the PRC subsidized NOC investment with hundreds of millions of dollars in economic assistance (Simao 2008). CNPC, largest of the NOCs, has financed port construction in Sudan, Pakistan, and Myanmar (Niazi 2005; Storey 2006). In 2006, it opened an overland pipeline from Kazakhstan into China through the city of Urumqi and in October 2009, CNPC began construction of a 500-mile overland oil and gas pipeline through from the Myanmar coast to the Yunnan city of Kunming (Blanchard \& Aizhu, 2010).

${ }^{31}$ Spencer, R. (2009). China prepares to buy up foreign oil companies. Telegraph. Retrieved from http://www.telegraph.co.uk/finance/newsbysector/-energy/4781037-/China-prepares-to-buy-upforeign-oil-companies.html.

${ }^{32}$ Sainsbury, M. (2010). Venezuela the latest destination on China's world tour. The Australian. Retrieved from http://www.theaustralian.com.au/business/-venezuela-the-latest-destination-onchinas-world-tour/story-e6frg8zx 1225858539325.

${ }^{33}$ Wood, Mackenzie. (2010). Chinese NOCs Step Up International Expansion. M\&A Service Report. Edinburgh: Wood Mackenzie. 


\section{C.Vinodan}

${ }^{34}$ Spencer, R. (2009). China prepares to buy up foreign oil companies. Telegraph. Retrieved from http://www.telegraph.co.uk/finance/newsbysector/-energy/4781037-/China-prepares-to-buy-upforeign-oil-companies.html.

35 Yunchang Jeffrey Bor, \& ZhongXiang Zhang. (2010). Asian Energy in the Context of growing Security and Environmental Concerns. Energy Economics, 32(1),1-2.

${ }^{36}$ Collier, R. (2005, June 26). China on global hunt to quench its thirst for oil. San Francisco Chronicle 2005. Retrieved from http://www.sfgate.com/cgi-bin/article.cgi?file=/c/a/2005/06/26/ MNG27DF8HQ1.DTL.

${ }^{37}$ Lelyveld, M. (2006, January 25). China Faulted for Africa Oil Deals. Radio Free Asia. Retrieved from http://www.rfa.org/english/features/lelyveld/2006/01/25/china_africa.

${ }^{38}$ SCO was formed in 2001 by the leaders of China, Russia and the Central Asian nations of Kazakhstan, Kyrgyzstan, Tajikistan, and Uzbekistan primarily to deal with terrorism and separatist threats in the region. Energy policy and the development of a common infrastructure have become a recent focus of activity.

${ }^{39}$ Fairclough, G. (2006, June 16). Politics \& Economics: Iran Lobbies China, Russia to Help Curb US. The Wall Street Journal.

${ }^{40}$ Beehner, L. (2006). The Rise of the Shanghai Cooperation Organization, Council on Foreign Relations. Retrieved from http://www.cfr.org/publication/10883/rise_of_the_shanghai_cooperation_ organization.html\#4

${ }^{41}$ Auyezov, Olzhas. ( 2009). Kazakhstan Expands China Oil Pipeline Link Reuters. Retrieved from http://www.reuters.com/article/idUSL17937520090701.

${ }^{42}$ Lai, Hongyi H. (2007). China's oil diplomacy: Is it a global security threat? Third World Quarterly, 28(3), 519-537.

${ }^{43}$ Lum, Thomas, Hannah Fischer, Julissa Gomez-Granger, \& Anne Leland. (2009). China's foreign aid activities in Africa, Latin America, and Southeast Asia. CRS Report to Congress. Washington, D.C.: Congressional Research Service.

${ }^{44}$ Ibid.

${ }^{45}$ Cook, Nicole. (2008). China's foreign policy and 'Soft Power' in South America, Asia, and Africa: CRS study prepared for the committee on foreign relations, United States Senate. Washington, D.C.: Congressional Research Service.

46 Stockholm International Peace Research Institute. (2010). Arms transfer database. Stockholm: SIPRI.

${ }^{47}$ Newmyer, Jacqueline. (2009). Oil, arms, and influence: The indirect strategy behind Chinese military modernization. Orbis, 53(2), 205-219. 


\section{References}

Aaron, L. F. (2010). The geopolitics of strategic Asia 2000-2020. The National Bureau of Asian Research, Washington D.C.; Lord, Malloch-Brown. (2010). Is Asia's rise inevitable? Asian Affairs, XLI(III), November.

Auyezov, O. ( 2009). Kazakhstan Expands China Oil Pipeline Link Reuters. Retrieved from http://www.reuters.com/article/idUSL17937520090701.

Barton, B., Redgwell, C., Ronne, A., \& Zillman, D. N. (Eds.) (2004). Energy security: Managing risk in a dynamic legal and regulatory environment. Oxford: Oxford University Press.

Beehner, L. (2006). The Rise of the Shanghai Cooperation Organization, Council on Foreign Relations. Retrieved from http://www.cfr.org/publication/10883/rise_of_ the_shanghai_cooperation_organization.html\#4

Cheng, J. Y. S. (2008). A Chinese View of China's Energy Security. Journal of Contemporary China, 17(55), 297-317.

Collier, R. (2005, June 26). China on global hunt to quench its thirst for oil. San Francisco Chronicle 2005. Retrieved from http://www.sfgate.com/cgi-bin/article.cgi?file=/ c/a/2005/06/26/MNG27DF8HQ1.DTL.

Cook, N. (2008). China's foreign policy and 'Soft Power' in South America, Asia, and Africa: CRS study prepared for the committee on foreign relations, United States Senate. Washington, D.C.: Congressional Research Service.

Dennis, B., \& Ellina, L. (2011). Facing China's coal future: Prospects and challenges for CCS. International Energy Agency. Retrieved from www.iea.org/publications/ insights/Chinas_coal_future.pdf.

Downs, E. S. (2004). The Chinese energy security debate. The China Quarterly, 177, 21-41.

Economist. (2007, August 4). Briefing: China's military might - The long march to be a superpower.

EIA (Energy Information Agency). (2005, August). Country analysis briefs China, 2005. Retrieved from http://www.eia.gov/emeu/cabs/china.html

Fairclough, G. (2006, June 16). Politics \& Economics: Iran Lobbies China, Russia to Help Curb US. The Wall Street Journal. 


\section{C.Vinodan}

Hamilton, L. H. (2005). Foreword. In J. H. Kalicki, \& D. L. Goldwyn (Eds.). Energy and security: Toward a new foreign policy strategy (p. xxi). Washington: Woodrow Wilson Center Press.

Hancher, L., \& Janssen, S. (2004). Shared competences and multi-faceted concepts European legal framework for security of supply. In B. Barton, C. Redgwell, A. Ronne, \& D. N. Zillman (Eds.). Energy security: Managing risk in a dynamic legal and regulatory environment (pp. 85 - 119). Oxford: Oxford University Press.

Hauser, G., \& Kernic, F. (Eds.) (2009). China: The Rising Power Frankfurt am Main, Berlin, Bern, Bruxelles, New York, Oxford, Wien (pp. 215-16).

Houser, T. (2008). The roots of Chinese oil investment abroad. Asia Policy 5 (January), 141-166.

International Energy Agency. (2009). Key world energy statistics. Paris: IEA.

International Energy Agency. (2011). Retrieved from http://www.iea.org

Kleveman, L. (2003). The new great game: Blood and oil in central Asia. New York: Grove Press.

Lai, H. H. (2007). China's oil diplomacy: Is it a global security threat? Third World Quarterly, 28(3), 519-537.

Lelyveld, M. (2006, January 25). China faulted for Africa oil deals. Radio Free Asia. Retrieved from http://www.rfa.org/english/features/lelyveld/2006/01/25/china_ africa.

Lum, T., Hannah F., Julissa G.-G., \& Anne L. (2009). China's foreign aid activities in Africa, Latin America, and Southeast Asia. CRS Report to Congress. Washington, D.C.: Congressional Research Service.

Newmyer, J. (2009). Oil, arms, and influence: The indirect strategy behind Chinese military modernization. Orbis, 53(2), 205-219.

Redgwell, C. (2004). International energy security. In B. Barton, C. Redgwell, A. Ronne, \& D. N. Zillman (Eds.). Energy security: Managing risk in a dynamic legal and regulatory environment (pp. 17 - 46). Oxford: Oxford University Press.

Rosen, D., \& Trevor, H. (2007 May). China energy: A guide for the perplexed. Peterson Institute for International Economics. Retrieved from http://www.petersoninstitute. org/publications/papers/rosen0507.pdf. 
Sainsbury, M. (2010). Venezuela the latest destination on China's world tour. The Australian. Retrieved from http://www.theaustralian.com.au/business/-venezuelathe-latest-destination-on-chinas-world-tour/story-e6frg8zx 1225858539325.

Spencer, S., \& Shai, O. (2010, July 18.). China tops U. S. in energy use. The Wall Street Journal.

Spencer, R. (2009). China prepares to buy up foreign oil companies. Telegraph. Retrieved from http://www.telegraph.co.uk/finance/newsbysector/-energy/4781037-/Chinaprepares-to-buy-up-foreign-oil-companies.html.

Stockholm International Peace Research Institute. (2010). Arms transfer database. Stockholm: SIPRI.

Stratford. (2010, February 11). China: The dragon of inflation. Stratford Analysis.

Wacker, G. (Ed.) (2006). Chinas Aufstieg: Rückkehr der Geopolitik? Berlin: Stiftung Wissenschaft und Politik (SWP-Studie 2006/S 03), Publications of the German Development Institute Nomos Verlagsgesellschaft; Scholvin, S. (2007). Die Energiepolitik neuer regionaler Führungsmächte, Hamburg: German Institute of Global and Area Studies / Leibniz-Institut für Globale und Regionale Studien (GIGA Focus 5).

Wen-Sheng Chen. (2010). China's oil strategy: "Going Out" to Iran. Asian Politics \& Policy, 2 (January/March), 39-54.

Willrich, M. (1975). Energy and world politics.New York: Free Press. p. 67.

Wood, M. (2010). Chinese NOCs Step Up International Expansion. M\&A Service Report. Edinburgh: Wood Mackenzie.

World Energy Outlook. (2010). Retrieved from www.worldenergyoutlook.org/media/ weo2010.pdf.

Yunchang J. B., \& ZhongX. Z. (2010). Asian Energy in the Context of growing Security and Environmental Concerns. Energy Economics, 32(1),1-2.

Zweig, D., \& Jianhai Bi. (2005). China's Global Hunt for Energy. Foreign Affairs, 84(5), 25-38. 
